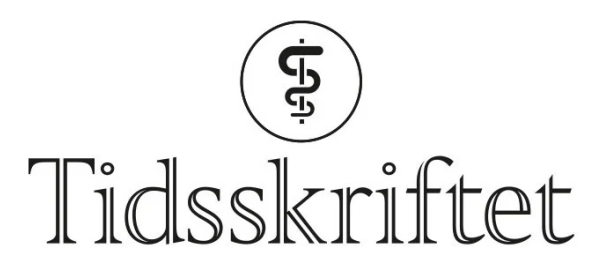

DEN NORSKE LEGEFORENING

\title{
Hva er en god lege?
}

LEGELIVET

OLAF GJERLøW AASLAND

olaf23o6@gmail.com

\section{En god lege er en lege som først ser hva slags lege pasienten trenger, og så går inn i den rollen.}

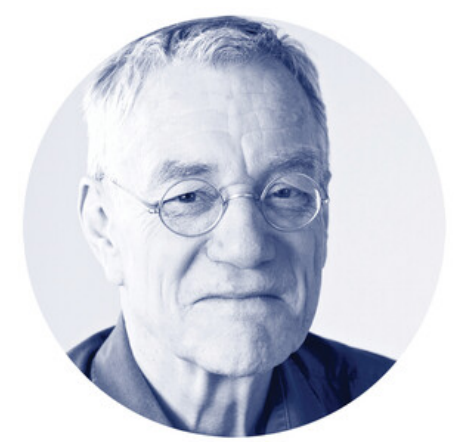

Foto: Einar Nilsen

Nylig ble jeg spurt om jeg kunne beskrive med tre ord hva som kjennetegner en god lege, som for eksempel kompetent, lyttende og empatisk. Men jeg kom til at det ikke er mulig, og kanskje heller ikke ønskelig, å gjøre en slik øvelse. Om man er en god lege, vil være avhengig av situasjonen, og ikke minst av pasienten. Noen pasienter foretrekker leger som kan være som en god venn eller nabo, som det er mulig å diskutere diagnostikk og behandling med. Andre pasienter vil helst ha en lege som er selvsikker, kategorisk og handlekraftig og som de kan se opp til. En god lege bør kunne spille flere roller.

I en klassisk artikkel fra USA beskriver forfatterne fire forskjellige legeroller langs et kontinuum som går fra en «kunden har alltid rett»-lege til en god gammeldags paternalist som bestemmer alt uten å snakke med pasienten (1). For hver enkelt pasient, og for hver enkelt lege, vil det også være stor individuell variasjon i hva som oppleves som godt, blant annet avhengig av diagnose, pasientens personlighet og sosioøkonomiske status samt pårørendes eventuelle medvirkning. Alt dette finnes der ute, i alle kombinasjoner.

\section{Rollespill}

For mange år siden var jeg lege på et legekontor for bostedsløse, på et sosialkontor og på arbeidsformidlingen - samtidig. Da hendte det at jeg traff den samme klienten på flere av disse stedene, og det var som å treffe helt forskjellige personer. Klienten ble kanskje 
overrasket over å treffe den samme legen flere steder i systemet, men vi gjennomførte likevel vårt rollespill. For lege-pasient-møtet er et klassisk rollespill der begge parter har definerte roller, bestemt av møtets hensikt. Men det er også et møte mellom to ikkelikeverdige parter, der pasienten er prisgitt legens bestemmelser. Ofte inngår det i legens rolle å være pasientens advokat eller samfunnets portvakt, ved å dokumentere behov for annen hjelp, medisinsk, sosialt eller økonomisk, som i mitt eksempel.

\section{«For nordmenn flest er nok en typisk lege allmennlegen»}

For nordmenn flest er nok en typisk lege allmennlegen, selv om bare vel $20 \%$ av de yrkesaktive legene i Norge arbeider som fastleger. Det var nok også en slik lege de som stilte spørsmålet jeg innledet med, hadde i tankene. Vi har en stolt tradisjon med en landsdekkende legetjeneste, som nå dessverre begynner å skrante som følge av manglende vedlikehold og dårlig rekruttering. Dette står i motsetning til spesialisthelsetjenesten, der et stadig økende flertall av legene arbeider. Den er et pengesluk, blant annet fordi legeantallet vokser eksponentielt. Mens et viktig måltall utenfor sykehus er antall innbyggere per lege, er det i sykehuset mer aktuelt å snakke om antall leger per pasient. For pasienten som stadig møter nye leger, blir det vanskelig å spille lege-pasient-rollespillet.

\section{Pasientkontakt}

Når det blir stadig flere sykehusleger mens pasientantallet ikke endrer seg særlig, betyr det at hver enkelt lege får mindre direkte pasienttid. Dette viser også våre tidsbrukundersøkelser. I likhet med alle oss andre tilbringer sykehuslegene stadig mer tid foran skjermen, særlig for å dokumentere og kvalitetssikre arbeidet de gjør. Men også det klassiske lege-pasient-rollespillet blir i økende grad virtuelt, noe som nødvendigvis vil påvirke rollene. Hva vil da kjennetegne en god lege? En med god datakompetanse? En som er fotogen? La oss håpe at dette nye kommunikasjonsuniverset også bringer noen fordeler, ikke bare distanse og fremmedgjøring.

\section{"La oss håpe at dette nye kommunikasjonsuniverset også bringer noen fordeler, ikke bare distanse og fremmedgjøring»}

Legeutdanningen er en grunnutdanning som gir store muligheter til videre spesialisering og differensiering. Selv allmennmedisin har for lengst blitt en egen spesialitet. Det er mulig å velge en karriere med lite eller ingen pasientkontakt, for eksempel innen grunnforskning eller administrasjon. Kanskje er det her en viss naturlig seleksjon i den forstand at medisinere med dårlig klinisk kommunikasjonsevne velger en pasientfri karriere. Men dessverre finnes det også eksempler på at leger som ikke evner å forholde seg godt til pasienter, nettopp velger å gjøre det. Disruptive physicians er et tilbakevendende tema i internasjonal legeforskning: leger med inflaterte ego som ingen tør å korrigere. Flere av professorene som underviste vårt kull for over 50 år siden var nok blant disse. I dag vil en slik lege få problemer, ikke minst fordi det er lettere for pasienter og kolleger å melde fra om trakassering og annen uønsket atferd.

Mitt svar på hva som kjennetegner en god lege, vil ut fra dette derfor være betinget av arbeidssituasjon og grad av pasientkontakt. For en allmennlege eller privatpraktiserende spesialist med hovedsakelig én-til-én-pasientmøter, vil den viktigste egenskapen være evnen til først å se pasienten, så finne ut hva slags lege akkurat denne pasienten trenger der og da, for deretter å gå inn i denne rollen, enten det er som kamerat, konsulent eller paternalist. For alle leger er det viktigste etter min mening å være seg bevisst sitt profesjonelle etiske ansvar. Selv om både helsepersonelloven (der legeyrket er sidestilt med 
28 andre helseyrker) og demografien (hver 150. innbygger er nå lege) forteller oss at det ikke lenger er noe spesielt å være lege, er det likevel det. Folk vil gjerne at det skal være det. Min definisjon på en lege er derfor:

En lege er et helt vanlig menneske som det forventes noe mer enn vanlig fra.

\section{LITTERATUR}

1. Emanuel EJ, Emanuel LL. Four models of the physician-patient relationship. JAMA 1992; 267: 2221-6. [PubMed][CrossRef]

Publisert: 8. oktober 2021. Tidsskr Nor Legeforen. DOI: 10.4045/tidsskr.21.0645

(C) Tidsskrift for Den norske legeforening 2023. Lastet ned fra tidsskriftet.no 26. april 2023. 